\title{
The Effect of Liquidity, Leverage and Firm Size of Financial Distress
}

Dian Primanita Oktasari" Faculty of Economics and Business, Universitas Mercu Buana

\section{Article History}

Received: 16.09 .2020

Accepted: 26.09 .2020

Published: 30.09 .2020

Journal homepage:

http://www.easpublisher.com/easjals/

\begin{abstract}
The long-term goal to be achieved in this research is to provide understanding and knowledge to the public, especially investors and creditors regarding the Effect of Liquidity, Leverage and Firm Size on Financial Distress and can be used as a reference for future researchers and stakeholders (investors, creditors and government) in making relevant and reliable decisions. The result is liquidity and company size positive significant and leverage does not have a significant effect on financial distress.

Keywords: liquidity, leverage, firm size, financial distress.
\end{abstract}

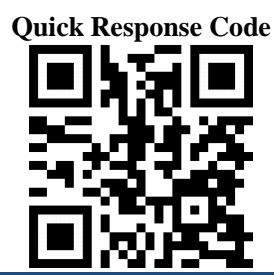

Copyright @ 2020: This is an open-access article distributed under the terms of the Creative Commons Attribution license which permits unrestricted use, distribution, and reproduction in any medium for non-commercial use (Non Commercial, or CC-BY-NC) provided the original author and source are credited.

\section{INTRODUCTION}

In the era of globalization, companies are demanded to be increasingly able to compete by showing various advantages to dominate the world market because free trade makes companies not only compete in the domestic sphere but also compete with foreign companies [1]. However, if a company is unable to compete, the company will suffer losses, which in turn can make a company experience financial distress [2].

According to Ross, Westerfield and Jaffe [3] financial distress is a situation where the company's operating cash flow is insufficient or does not meet current obligations (such as trade credit or interest expense) and the company is forced to take corrective actions, and that may involve financial restructuring between companies, its creditors, and its equity investors. Financial distress is a broad concept that consists of several situations where a company faces financial difficulties [4].

According to Koharyanto and Jogi [5]. The mining sector is one of the pillars of a country's economic development. This is because the mining sector acts as a provider of energy resources that are very necessary for a country's economic growth.

According to Altman in the occurrence of financial distress can be predicted by the company's financial ratios. As in this study, the ratios used are liquidity, leverage and firm size.

\section{Literature Review}

\section{Signalling Theory}

Signal theory begins with the writings of George Akerlof in his 1970 work "The Market for Lemons", which introduces a term asymmetric information (assymetry information). Akerlof 1970also learns about the phenomenon of imbalance information about the quality of a product between buyers and sellers by testing the used car market.The condition where one party (the seller) who conducts a business transaction has more information about the other party (the buyer) is called adverse selection Scott, 2015.

\section{Financial Distress}

Ellen and Juniarti, financial distress as a condition in which companies experience irregularities and financial pressures that will gradually lead to bankruptcy. Bankruptcy is usually interpreted as a failure of a company in carrying out company operations to generate profits [6]. According to Ross, Westerfield and Jaffe [3], financial distress is a situation where a company's operating cash flow is insufficient or does not meet current obligations (such as trade credit or interest expense) and the company is forced to take corrective actions, and that may involve financial restructuring between the company, its creditors and equity investors. According to Hery [7], financial difficulties begin when the company cannot meet the payment schedule, or when cash flow projections indicate that the company will soon be unable to meet its obligations. 


\section{Liquidity Ratio}

The liquidity ratio has an effect on financial performance [8].The liquidity ratio is a ratio that describes the company's ability to meet short-term obligations that are due soon. Liquidity ratios are needed for credit analysis or financial ratio analysis [7]. According to Ayu, Handayani and Topowijono [1], the liquidity ratio is a ratio that measures the company's short-term liquidity ability by looking at the company's current assets to its current debt.

\section{Leverage}

According to Kasmir [9] leverage ratio (solvency ratio) is a ratio used to measure the extent to which a company's assets are financed with debt. That is, the large amount of debt used by companies to finance their business activities when compared with their own capital. Leverage is to answer the question of how a company funds its assets. This ratio provides a measure of the funds provided by the owner compared to the finances of creditors [10].

\section{Firm Size}

Firm size is a scale in which the size of the company can be classified according to various ways, including the total assets, $\log$ size, market value of shares, and others. The size of the company will affect the ability to bear the risks that may occur from various situations faced by the company [11].

\section{Hypothesis}

Referring to the research objective, which is to analyze the financial statements as a predictor of bankruptcy in banking companies listed on the Indonesia Stock Exchange, the research hypotheses proposed are as follows:

a. H1: Liquidity has a Positive Impact on Financial Distress

b. H2: Leverage Has a Positive Effect on Financial Distress

c. H3: Firm Size has a negative effect on financial distress

Based on the hypotheses developed above, an illustration can be given in the form of a chart about the influence of the independent variables namely Liquidity, Leverage and Firm Size on the dependent variable, namely Financial Distress as follows:

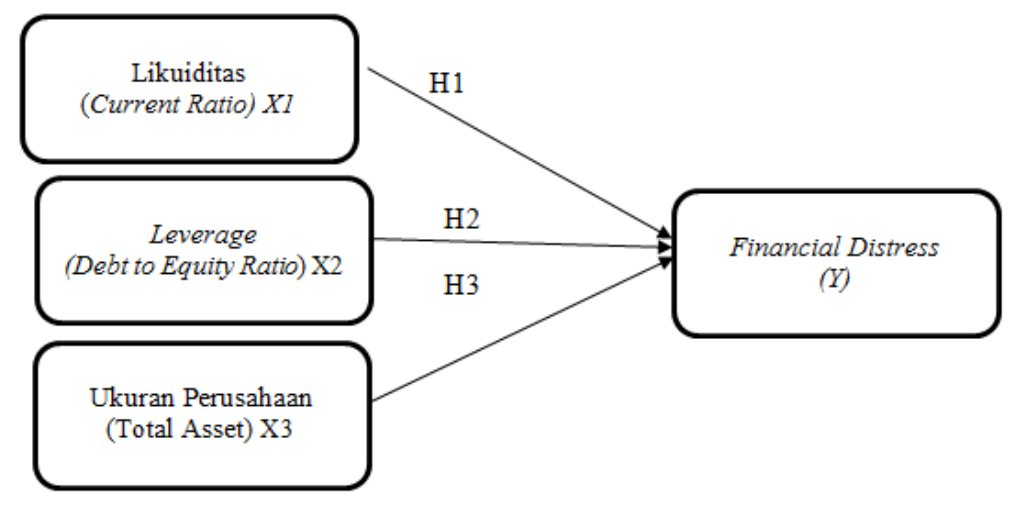

Fig-1: Framework

\section{ReSEARCH DeSIGN AND METHOD}

\section{Operationalization of Variables and Measurement of Variables}

Table-1: Operationalization of Variables and Measurement of Variables

\begin{tabular}{|c|c|c|c|}
\hline No. & Variabel & Rumus & Skala \\
\hline 1.11 & $\begin{array}{c}\text { Financial Distress (Springate) } \\
(\mathrm{Y})\end{array}$ & $\mathrm{S}=1,03 \mathrm{~A}+3,07 \mathrm{~B}+0,66 \mathrm{C}+0,4 \mathrm{D}$ & RRRasio \\
\hline 2.22 & $\begin{array}{c}\text { Likuiditas (Current Ratio) } \\
(\mathrm{X} 1)\end{array}$ & $\mathrm{CR}=\frac{\text { Aktiva Lancar }}{\text { Hutang Lancar }}$ & RR Rasio \\
\hline 3.33 & $\begin{array}{c}\text { Leverage (Total Debt to } \\
\text { Equity Ratio) (X2) }\end{array}$ & Total Debt Equity Ratio $=\frac{\text { Total Hutang }}{\text { Total Ekuitas }}$ & Rasio \\
\hline 4.44 & $\begin{array}{c}\text { Ukuran Perusahaan (Ln Total } \\
\text { Asset) (X3) }\end{array}$ & Ukuran Perusahaan $=$ Ln Total Asset & Ra Rasio \\
\hline
\end{tabular}

Population and Research Samples 
The population in this study are all mining companies listed on the Indonesia Stock Exchange. This study uses secondary data from the financial statements of mainig companies in 2014 - 2018. Data in this study were taken by purposive sampling method, with the following criteria:

1. Mining sector company

2. Publish financial statements in rupiah and issue audited financial statements as of December 31.

3. No de-listing during 2013 - 2017.

4. Have complete data following the needs of the author

\section{Data Analysis Method}

Data analysis was performed using the Eviews 8 program which included analysis as follows: 1) Test Descriptive Statistics. 2) Inferensial Statistic, Common Effect. Fixed Effect. Random Effect.3) Model Testing (Selecting the Data Panel Model); Uji Chow (F Statistik) and Haussman test. 4) Regression Testing Model 5). Feasibility Test Model consisting of Analysis of the Determination Coefficient (R2 test), Simultaneous Regression Coefficient Test (F Test) and Partial Test (t Test).

\section{RESUlts}

Ghozali 2013 argues that the test basically shows how far the influence of one explanatory / independent variable individually in explaining the variation of the dependent variable.

Tabel-1: t-test

\begin{tabular}{|l|l|l|l|l|}
\hline Variable & $\begin{array}{l}\text { Coefficien } \\
\mathbf{t}\end{array}$ & Std. Error & t-Statistic & Prob. \\
\hline C & -3.431645 & 1.152193 & -2.978360 & 0.0064 \\
\hline LIKUIDITAS & 0.920395 & 0.247194 & 3.723378 & 0.0010 \\
\hline LEVERAGE & 0.202522 & 0.151423 & 1.337460 & 0.1931 \\
\hline $\begin{array}{l}\text { UKURANPERUSAH } \\
\text { AAN }\end{array}$ & 0.750506 & 0.278277 & 2.696969 & 0.0123 \\
\hline
\end{tabular}

\section{a. Effect of Liquidity on Financial Distress}

Based on tests conducted using the Fixed Effect model described in Table 1 that the Liquidity variable has a t-statistic value of 3.723378 and a smaller significance level $(0.0010<0.05)$. thus the results of the analysis in this study indicate $\mathrm{HO}$ is rejected and $\mathrm{Ha}$ is accepted which means that the Liquidity variable influences Financial Distress.

H1: Liquidity has a significant positive effect on the likelihood of Financial Distress.

\section{b. Effect of Leverage on Financial Distress}

Based on tests conducted using the Fixed Effect model as described in Table 1 that the Leverage variable has a t-statistic value as large as 1.337460 and has a significantly greater level $(0.1931>0.05)$. thus the results of the analysis in this study indicate $\mathrm{H} 0$ is accepted and $\mathrm{Ha}$ is rejected which means that the Leverage variable does not have a significant effect on Financial Distress.

$\mathrm{H}$ 2: Leverage does not have a significant effect on the likelihood of Financial Distress.

\section{c. Effect of Company Size on Financial Distress}

Based on tests conducted using the Fixed Effect model as described in Table 1 that the Company Size variable has a t-statistic value of 2.696969 and has a significantly smaller level $(0.0123<0.05)$. thus the results of the analysis in this study indicate that $\mathrm{HO}$ is rejected and $\mathrm{Ha}$ is accepted, which means that the Company Size variable has a significant positive effect on Financial Distress.
H3: Company size has a significant positive effect on the likelihood of Financial Distress

\section{DISCUSSION}

After presenting the results, you are in a position to evaluate and interpret their implications, especially with respect

\section{Effect of Liquidity on Financial Distress}

Based on the results of testing the hypothesis shows that liquidity has a positive and significant effect on the likelihood of Financial Distress. Which according to Hery [7], liquidity ratio is a ratio that illustrates the company's ability to meet its short-term obligations that are due soon. This can indicate that the greater the liquidity of a company, the greater the company's ability to cover its current debt. The greater the value of a company's liquidity, the greater the company's ability to cover its current debt. The greater the company's liquidity means the company's current assets are able to cover the company's current debt. However, the high liquidity ratio does not necessarily make the company experience no financial difficulties. Factors that cause this phenomenon can occur because the company has decreased sales every year and the use of assets of the company is not productive, so that the increase in liquidity ratio and not followed by increased earnings received. According to Triwahyuningtyas and Muharam, which states that the higher the value of liquidity, the greater the current assets that are not needed, so that it does not provide income and a large 
amount of funds will be collected in the form of trade receivables that may prove uncollectible. Unsettled receivables or unsold inventory cannot be used by companies to pay debts. The high level of liquidity indicates that there is an excess of current assets which has a bad influence on the profitability of the company. Thus causing other factors that can affect the company experiencing financial distress.

This study is in line with research conducted by Aisyah, Kristanti and Zultilisna [4], Cinantya and Merkusiwati [12] and Ufo [20] which states that liquidity has a significant positive effect on the likelihood of Financial Distress.

This study is not in line with the results of research conducted by Andre and Taqwa [2], Putri and Merkusiwati [13] who stated that Liquidity has a significant influence on the likelihood of Financial Distress.

\section{Effect of Leverage on Financial Distress}

Based on the results of hypothesis testing shows that leverage does not have a significant effect on the likelihood of Financial Distress. Which according to Kasmir [9] states that the leverage ratio (solvency ratio) is a ratio used to measure the extent to which a company's assets are financed with debt. The measuring instrument used is Debt to Equity Ratio (DER), which is total debt divided by total equity. The higher the funds provided by creditors with company owners, the lower the likelihood of financial distress.

This study is in line with research conducted by Putri and Merkusiwati [13], Cinantya and Merkusiwati [12], Ayu, Handayani and Topowijoyo [1] which states that Leverage has no influence on the likelihood of Financial Distress.

This research is not in line with research conducted by Gobenvy [14], Andre and Taqwa [2], Rahmadani, Sujana and Darmawan [1] which states that leverage has a significant influence on the likelihood of Financial Distress.

\section{Effect of Company Size on Financial Distress}

Hypothesis testing results indicate that company size has a positive and significant influence on the likelihood of Financial Distress. According to Fitdini's research [15], it means that the smaller the size of the company, the greater the tendency to experience financial distress. According to Steven [4], this is because the smaller the company, the higher the growth opportunities and therefore, tends to face conflicts of interest between the principal and the agent, so as to reduce the agency cost of debt, the smaller companies will borrow more.

In general, the size of the company can be interpreted as a comparison of the size of the object [7].
The larger the size of a company is expected to be able to settle obligations in a timely manner, so that the risk of financial distress gets smaller [16].

This study is in line with research conducted by Putri and Merkusiwati [17] and Sayari and Mugan [18] which states that Company Size has a significant positive effect on the likelihood of Financial Distress.

This research is not in line with research conducted by Ayu, Handayani and Topowijoyo [1], Cinantya and Merkusiwati [12] and Harahap [19] which states that Company Size has no influence on Financial Distress.

\section{Conclusions}

This study aims to examine the effect of Liquidity, Leverage, and Firm Size on Financial Distress Studies in Mining Sector Companies Listed on the Indonesia Stock Exchange in the 2014-2018 Period. Based on the results of the analysis, the conclusions that can be drawn from this study are as follows:

a) Liquidity has a significant positive effect on Financial Distress in Mining Sector Companies Listed on the Indonesia Stock Exchange for the 2014-2018 Period. The higher the liquidity, the greater the current assets that are not needed, so they do not provide income and a large amount of funds will be collected in the form of trade receivables that may prove to be uncollectible. Uncollectible receivables or unsold inventory cannot be used by the company to pay debts.

b) Leverage has no influence on Financial Distress in Mining Sector Companies Listed on the Indonesia Stock Exchange in the 2014-2018 Period.

c) Company size has a positive and significant influence on Financial Distress in Mining Sector Companies Listed on the Indonesia Stock Exchange in the 2014-2018 Period. meaning that the smaller the size of the company will have a tendency to experience greater financial distress. That is because the smaller the company, the growth opportunities will be higher and hence, tend to face conflicts of interest between the principal and the agent, so to reduce the agency cost of debt, the smaller companies will borrow more.

\section{REFERENCES}

1. Ayu, A. S., \& Handayani, S. R. (2017). Pengaruh Likuiditas, Leverage, Profitabilitas, dan Ukuran Perusahaan Terhadap Financial Distress Studi pada Perusahaan Manufaktur Sektor Industri Dasar dan Kimia yang Terdaftar di Bursa Efek Indonesia tahun 2012-2015. Jurnal Administrasi Bisnis, 43(1), 138-147.

2. Andre, O., \& Taqwa, S. (2014). Pengaruh Profitabilitas, Likuiditas, dan Leverage Dalam Memprediksi Financial Distress (Studi Empiris 
Pada Perusahaan Aneka Industri yang Terdaftar di BEI Tahun 2006-2010). Wahana Riset Akuntansi, 2(1).

3. Ross, Stephen, A., Westerfield, Randolph, W., Jaffe, Jeffrey, J. B.D. (2013). Corporate Finance $\left(11^{\text {th }}\right.$ ed). New York, NY 10121.

4. Aisyah, N., Kristanti, F., \& Zutilisna, D. (2017). Pengaruh Rasio Likuiditas, Rasio Aktivitas, Rasio Profitabilitas, Dan Rasio Leverage Terhadap Financial Distress (studi Kasus Pada Perusahaan Tekstil Dan Garmen Yang Terdaftar Di Bursa Efek Indonesia Tahun 2011-2015). eProceedings of Management, 4(1).

5. Koharyanto, J. A. (2016). Respon Investor Di Sektor Pertambangan Terhadap Pengumuman PSAK No. 64: Aktivitas Eksplorasi dan Evaluasi Pada Pertambangan Sumber Daya Mineral. Business Accounting Review, 4(2), 157-168.

6. Safitri, Aprilia., \& Hartono, Ulil. (2014). Uji Penetapan Mmodel Prediksi Financial Distress Altman, Springate, Ohlson Dan Zmijewski Pada Perusahaan Sektor Keuangan di Bursa Efek Inonesia. Jurnal Ilmu Manajemen, 2(2).

7. Hery, 2017. Kajian Riset Akuntansi: Mengulas Berbagai Hasil Penelitian Terkini Dalam Bidang Akuntansi dan Keuangan. Jakarta: PT Gramedia Pustaka Utama.

8. Firdaus, I., \& Sedias,S.R.B.(2017). Pengaruh Profitabilitas, Likuiditas Dan Struktur Modal Terhadap Kebijakan Dividen.Jurnal Ilmiah Manajemen dan Bisnis, 3(3).

9. Kasmir. (2013). AnalisisLaporanKeuangan. Jakarta: PT Raja Grafindo Persada.

10. Kamaludin, I.R. (2012). Manajemen Keuangan "Konsep Dasar dan Penerapannya". Bandung: CV. Mandar Maju.

11. Prasetyorin, F., \& Fitri, B. (2013). Pengaruh ukuran perusahaan, leverage, price earning ratio dan profitabilitas terhadap nilai perusahaan. Jurnal Ilmu Manajemen (JIM), 1(1).

12. Cinantya, I. G. A. A. P., \& Merkusiwati, N. K. L. A. (2015). Pengaruh Corporate Governance, Financial Indicators, Dan Ukuran Perusahaan Pada Financial Distress. E-Jurnal Akuntansi, 897-915.
13. Putri, N. W. K. A., \& Merkusiwati, N. K. L. A. (2014). Pengaruh mekanisme corporate governance, likuiditas, leverage, dan ukuran perusahaan pada financial distress. E-Jurnal Akuntansi, 7(1)93-106.

14. Gobenvy, O. (2014). Pengaruh Profitabilitas, Financial Leverage dan Ukuran Perusahaan terhadap Financial Distress pada Perusahaan Manufaktur yang Terdaftar di Bursa Efek Indonesia Tahun 2009-2011. Jurnal Akuntansi, 2(1).

15. Widarjo, W., \& Setiawan, D. (2009). Pengaruh rasio keuangan terhadap kondisi financial distress perusahaan otomotif. Jurnal bisnis dan akuntansi, 11(2), 107-119.

16. Astuti, P., \& Pamudji, S. (2014). Analisis Pengaruh Opini Going Concern, Likuiditas, Solvabilitas, Arus Kas, Umur Perusahaan Dan Ukuran Perusahaan Terhadap Kemungkinan Financial Distress (Studi Empiris Pada Perusahaan Manufaktur Yang Terdaftar Di Bursa Efek Indonesia Tahun 2010-2013). (Doctoral dissertation, Fakultas Ekonomika dan Bisnis), 4(1):1-11

17. Sari, N. L. K. M., \& Putri, I. M. A. D. (2016). Kemampuan Profitabilitas Memoderasi Pengaruh Likuiditas Dan Leverage Terhadap Financial Distress. Jurnal Riset Akuntansi (JUARA), 6(1).

18. Sayari, N., \& Mugan, F. C. S. (2013). Cash flow statement as an evidence for financial distress. Universal Journal of Accounting and Finance, 1(3), 95-102.

19. Harahap, L. W. (2017). Pengaruh Mekanisme Corporate Governance dan Firm Size Terhadap Kondisi Financial Distress Pada Perusahaan Property and Real Estate Yang Terdaftar di BEI Tahun 2010-2014. JRAB: Jurnal Riset Akuntansi \& Bisnis, 17(2).

20. Yuliastary, E. C., \& Wirakusuma, M. G. (2014). Analisis Financial Distress dengan Metode Z-Score Altman, Springate, Zmijewski. E-Jurnal Akuntansi, 6(3)379-389. 